\title{
Pengelompokan Kabupaten/Kota Provinsi Sulawesi Selatan dan Barat Berdasarkan Angka Partisipasi Pendidikan SMA/SMK/MA Menggunakan K-Medoid dan CLARA
}

\author{
Wardianti AS.*, Muhammad Kasim Aidid, \& Muhammad Nusrang \\ Program Studi Statistika, Fakultas Matematika dan Ilmu Pengetahuan Alam, Universitas Negeri Makassar, Indonesia
}

Keywords: Cluster analysis, CLARA, Educational partisipation, K-medoid.

\begin{abstract}
:
Cluster analysis is grouping objects by high similarity of characteristic in a cluster but high dissimilarity in another cluster. Cluster analysis is divided into hierarchical method and non hierarchical method. Hierarchical method use structur tree-like to determine its object in a cluster. The objects are placed to a similar centroid while cluster seed was determined in nonhierarchical method. The types of centroid are mean centroid and median centroid (known as medoid). The disadvantage of mean is not robust from outlier. Otherwise, $\mathrm{k}$-medoid is robust with outlier data. Big data problem is concerned, so CLARA is used to be a development from $\mathrm{k}$-medoid method. K-medoid and CLARA is applicated in this paper to clustering city of South Sulawesi and West Sulawesi based on the indicator of APP year 2017. APP was categorized into four levels, hence CLARA was build from a cluster which resulted from $\mathrm{k}$ medoid for four clusters. Generated silhouette value on the method $\mathrm{k}$-medoid and CLARA with same value $\mathrm{k}=4$ of 0,49 each methods. Furthermore, the characteristic of each group of CLARA method and $\mathrm{k}$-medoid were more clear than the APP groups, hence would be an alternative to map the city of Indonesia based on APP indicators year 2017.
\end{abstract}

\section{Pendahuluan}

Pendidikan yang tinggi selalu dipersyaratkan sebagai modal kemajuan sebuah bangsa. Sehingga tidak mengherankan jika pendidikan sampai saat ini menjadi perhatian Negara terbelakang ataupun berkembang. Adanya pendidikan yang memadai diharapkan akan dapat merubah pola pikir masyarakat ke arah yang lebih maju. Upaya peningkatan kualitas sumber daya manusia melalui bidang pendidikan telah lama dilakukan oleh pemerintah dengan melakukan akreditasi sekolah, standardisasi sekolah, dan wajib belajar 12 tahun (Badan Perencanaan Pembangunan Nasional, 2015).

Salah satu parameter keberhasilan pendidikan dapat dilihat dari indikator pendidikan disuatu daerah. Indikator pendidikan di Indonesia memiliki komponen yang berbeda-beda. Pengukuran Angka Partisipasi Pendidikan dapat digunakan untuk mengevaluasi keberhasilan tingkat pendidikan di suatu daerah. Namun diperlukan analisis lebih lanjut terhadap hasil pengukuran tersebut. Pengukuran Angka Partisipasi Pendidikan merupakan pengukuran multidimensi yang menggunakan banyak indikator. Oleh karena itu analisis yang dapat digunakan salah satunya adalah analisis kelompok. Analisis kelompok pertama kali digunakan Tyron pada tahun 1939.

Analisis pengelompokan merupakan salah satu teknik statistik yang bertujuan mengorganisasikan data menjadi beberapa kelompok sehingga tingkat kesamaan dalam kelompok tinggi dan tingkat kesamaan antar kelompok rendah.

\footnotetext{
* Corresponding author.

E-mail address: wardianti.as@gmail.com
} 
Analisis kelompok (Clustering) adalah salah satu analisis peubah ganda (multivariate analysis) yang digunakan untuk mengelompokan objek-objek sedemikian rupa sehingga objek dalam satu kelompok yang sangat mirip dan objek di berbagai kelompok cukup berbeda (Rizal \& Hakim, 2015). Hasil pengelompokan diharapkan dapat bermanfaat dalam pengambilan kebijakan oleh pemerintah daerah tentang kabupaten/kota yang terbentuk dalam kelompok yang memerlukan perhatian lebih oleh pemerintah dalam perbaikan masalah pendidikan di suatu wilayah.

Menurut Halkidi (2001) algoritma pengelompokan dapat diklasifikasikan menjadi empat jenis, yaitu pengelompokan non-hierakri (partisi), pengelompokan hierarki, pengelompokan berdasarkan densitas, dan pengelompokan berdasarkan grid. Metode pengelompokan hirarki digunakan untuk mengelompokan pengamatan secara terstruktur berdasarkan sifat kemiripannya, dan kelompok yang diinginkan belum diketahui banyaknya. Sedangkan metode pengelompokan nonhierarki, digunakan untuk mengelompokan obyek-obyek pengamatan menjadi $k$ kelompok. Proses dari metode ini diawali dengan penentuan pusat kelompok dan penempatan anggota-anggota ke dalam pusat kelompok terdekat (Hair, 2010).

Metode pengelompokan tak berhierarkhi diantaranya yaitu $k$-medoid, $k$ - means, Fuzzy $k$-means dan CLARA (Kaufman \& Rousseauw, 1990). Menurut Chu dkk (2002), algoritma $k$-medoid dikatakan lebih robust (tegar) terhadap outlier jika dibandingkan dengan algoritma yang lain. $K$-medoid dapat mengelompokan dengan baik pada data berskala kecil. Data dengan skala besar dapat menggunakan Clustering Large Application (CLARA). CLARA merupakan sampling yang masing-masing contohnya dilakukan metode k-medoid. Hasil CLARA tergantung dari pemilihan contoh dan ukurannya. CLARA menghasilkan kelompok yang tetap pada setiap iterasi.

Sementara itu penerapan terkini metode $k$-medoid dan CLARA juga dilakukan oleh Syafrina (2015) \& Cahyadahrena (2015). Syafrina (2015) dalam tesisnya meneliti tentang pengelompokan daerah di Indonesia berdasarkan peubah Indeks Pembangunan Manusia (IPM) menggunakan metode Fuzzy $k$-rataan dan kmedoid.

Hasil yang diperoleh menyatakan bahwa metode $k$-medoid dapat mengelompokan dengan baik sesuai kriteria pengujian kebaikan kelompok perbandingan jarak rata-rata antar kelompok daripada hasil pengelompokan metode Fuzzy $k$-rataan dan $k$-rataan. Cahyadahrena (2015) dalam skripsinya meneliti tentang deteksi pencilan pada data titik panas menggunakan metode kmedoid dan CLARA. Hasil kedua metode tersebut digunakan sebagai metode untuk mengelompokan titik panas dan mendeteksi pencilan pada data titik panas.

Penelitian ini menerapkan metode $k$-medoid dan CLARA untuk mengelompokan kabupaten/kota di Provinsi Sulawesi Selatan dan Sulawesi Barat berdasarkan indikator penyusun Angka Partisipasi Pendidikan. Indikator tersebut meliputi Angka Partisipasi Kasar, Angka Partisipasi Murni, dan Angka Partisipasi Sekolah . Hasil pengelompokan dengan kedua metode tersebut diharapkan dapat memetakan daerah di Provinsi Sulawesi Selatan dan Barat ke dalam beberapa kelompok. Selain pengelompokan dengan kedua metode tersebut, pemetaan daerah di Provinsi Sulawesi Selatan dan Barat juga dapat dilakukan dengan pengkategorian berdasarkan nilai Angka Partisipasi Pendidikan.

Sesuai uraian diatas maka penulis bermaksud untuk mengkaji dan melakukan penelitian yang berjudul "Pengelompokan Kabupaten/Kota Provinsi Sulawesi Selatan dan Barat Berdasarkan Angka Partisipasi Pendidikan SMA/SMK/MA Menggunakan $k$-medoid dan CLARA".

\section{Metode Penelitian}

Jenis data yang digunakan dalam penelitian ini adalah data sekunder yang dipublikasikan oleh Badan Pusat Statistik (BPS) Provinsi Sulawesi Selatan dan Sulawesi Barat yaitu data Indikator Angka Partisipasi Pendidikan (APP) Tahun 2017. Data yang digunakan dalam permasalahan ini ada 3 indikator yaitu Angka Partisipasi Kasar (APK), Angka Partisipasi Murni (APM), dan Angka Partisipasi Sekolah. Obyek dari penelitian ini adalah kabupaten/kota di Provinsi Sulawesi Selatan dan Sulawesi Barat sebanyak 27 kabupaten dan 3 kota.

Adapun langkah-langkah analisis data dalam penelitian ini adalah:

1. Melakukan analisis statistika deskriptif terhadap peubah angka partisipasi kasar (X1), angka partisipasi murni (X2), dan angka partisipasi sekolah(X3). 
Deskripsi data dilihat dari peringkat tiga terbesar dan tiga terkecil dari masing masing peubah.

2. Mendeteksi pencilan dengan menggunakan diagram Boxplot dari masing masing peubah.

3. Melakukan pengelompokan dengan metode $k$-medoid terhadap data

4. Melakukan ukuran kelompok dengan metode $k$-medoid terhadap masing masing banyaknya kelompok dengan nilai silhouette dan menentukan kelompok terbaik berdasarkan nilai silhouette yang paling tinggi.

5. Melakukan pengelompokkan pada kelompok terbaik berdasarkan banyaknya kelompok dan kelompok sesuai pengkategorian nilai APP (3 kelompok) dengan metode $k$-medoid.

6. Melakukan pengelompokkan CLARA terhadap data

7. Melakukan ukuran kelompok dengan metode CLARA terhadap masing masing banyaknya kelompok dengan silhouette dan menentukan kelompok terbaik berdasarkan nilai silhouette yang paling tinggi

8. Melakukan pengelompokan pada kelompok terbaik berdasarkan banyaknya kelompok dan kelompok sesuai pengkategorian nilai APP (3 kelompok) dengan metode CLARA.

9. Memilih metode terbaik dengan nilai silhouette

\section{Hasil dan Pembahasan}

\subsection{Eksplorasi Data}

Analisis Statistika deskriptif digunakan untuk mengetahui gambaran secara umum karakteristik untuk masing-masing indikator atau peubah yang digunakan berdasarkan indikator Angka Patisipasi Pendidikan. Gambar 1 (Angka Partisipasi Sekolah), Gambar 2 (Angka Partisipasi Kasar), dan Gambar 3 (Angka Partisipasi Murni) menjelaskan peringkat tertinggi dan peringkat terendah dari masing-masing peubah. Berikut ini adalah data diskriptif dengan menggunakan gambar.

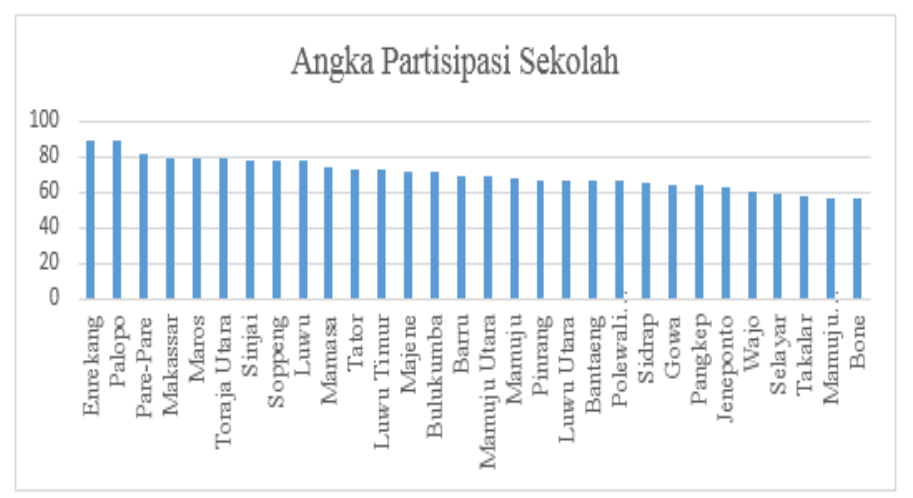

Gambar 1. Angka partisipasi Sekolah di 30 Kabupaten/Kota SulSel dan SulBar

Berdasarkan gambar 1. Nilai Angka Partisipasi Sekolah tertinggi jika diurutkan dari yang tertinggi banyak ditemukan di kabupaten/kota Provinsi Sulawesi Selatan yaitu Enrekang, Palopo, dan Pare-pare. Sementara nilai terendahnya berasal dari kabupaten/kota Provinsi Sulawesi Selatan dan Barat yaitu Takalar, Mamuju dan Bone. 


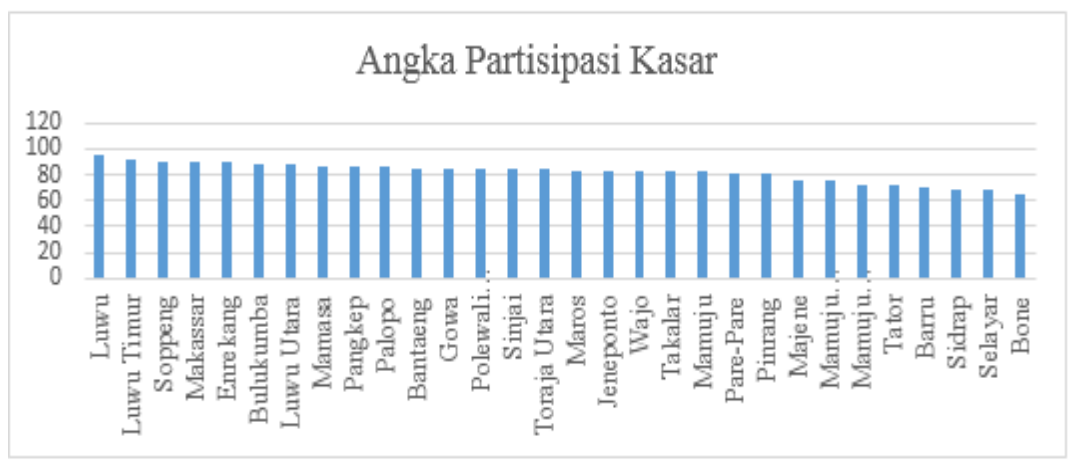

Gambar 2 Angka partisipasi Kasar di 30 Kabupaten/Kota SulSel dan SulBar

Pada indikator Angka Partisipasi Kasar (Gambar 2), peringkat tertinggi dan terendah berasal dari kabupaten/kota Provinsi Sulawesi Selatan. Nilai Angka Partisipasi Kasar tertinggi jika diurutkan dari yang tertinggi banyak ditemukan di kabupaten/kota Provinsi Sulawesi Selatan yaitu Luwu Utara, Luwu Timur dan Soppeng. Sementara nilai terendahnya berasal dari kabupaten/kota Provinsi Sulawesi Selatan dan Barat yaitu Sidrap, Selayar dan Bone.

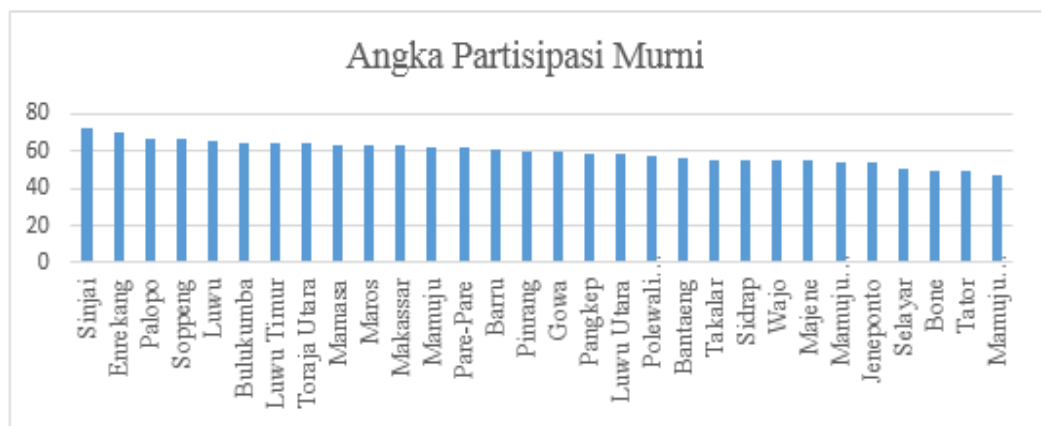

Gambar 3. Angka Partisipasi Murni di 30 Kabupaten/Kota SulSel dan SulBar

Indikator Angka Partisipasi Murni jika diurutkan dari yang tiga tertinggi terdapat di wilayah Provinsi Sulawesi selatan. Sementara nilai tiga terendah beragam berasal dari kabupaten/kota Provinsi Sulawesi Selatan dan Sulawesi Barat. Nilai tertinggi yaitu Sinjai, Enrekang, dan Palopo. Dan terendah yaitu Bone, Tana Toraja, dan Mamuju Tengah.

Tabel 1. Statsitika Deskriptif APS, APK, dan APM 30 Kabupaten/Kota Provinsi Sulawesi Selatan dan Barat Tahun 2017

\begin{tabular}{llll}
\hline Case & Angka Partisipasi Sekolah (\%) & Angka Partisipasi Kasar (\%) & Angka Partisipasi Murni (\%) \\
\hline Minimum & 56,52 & 65,24 & 46,78 \\
Kuartil 1 & 64,59 & 76,50 & 55,38 \\
Median & 68,94 & 83,47 & 59,88 \\
Mean & 70,19 & 81,72 & 59,30 \\
Kuartil 3 & 77,81 & 85,59 & 63,65 \\
Maksimum & 89,04 & 95,31 & 72,62 \\
\hline
\end{tabular}

Berdasarkan Tabel 1, dapat dilihat bahwa nilai rata-rata Angka Partisipasi Sekolah kabupaten/kota Provinsi Sulawesi Selatan dan Barat mencapai 70,19\%, dengan nilai minimum sebesar 56,52\% angka ini ditempati oleh kabupaten Bone dan nilai maksimum sebesar 89,04\% angka ini ditempati oleh kabupaten Enrekang, untuk nilai rata-rata Angka Partisipasi Kasar di kabupaten/kota Provinsi Sulawesi Selatan dan Sulawesi Barat. mencapai 81,72\%, dengan nilai minimum sebesar 65,24\% angka ini ditempati oleh kabupaten Bone dan nilai maksimum sebesar 95,31\% angka ini ditempati oleh kabupaten Luwu. Hal tersebut diakarenakan adanya kasus tinggal kelas atau terlambat masuk sekolah di Kabupaten Bone dan Kabupaten Luwu. Nilai Angka Partisipasi Murni kabupaten/kota Provinsi Sulawesi Selatan dan Barat mencapai 59,3\% dengan nilai minimum sebesar 46,78\% angka ini ditempati oleh kabupaten Mamuju 
Tengah dan nilai maksimum sebesar 72,62\% angka ini ditempati oleh kabupaten Sinjai. Perbedaaan nilai maksimum dan nilai minimum pada semua indikator menyebabkan banyaknya daerah yang mempunyai indikator dibawah ratarata.

\subsection{Pengelompokan Menggunakan Metode K-Medoid}

Banyaknya kelompok dalam pengelompokan menggunakan $k$-medoid dapat diinisiasi secara subjektif oleh peneliti. Banyaknya kelompok yang digunakan adalah 2, 3, 4 dan 5. Pengelompokan terbaik adalah pengelompokan $k$ dengan nilai koefisien silhouette optimum.

\subsubsection{Metode $k$-medoid dengan nilai $k=2$}

Pengelompokan berdasarkan nilai $\mathrm{k}=2$ dapat dilihat pada Gambar 4 dan Gambar 5. Dimana kelompok 1 memiliki nilai silhouette sebesar 0,41 dengan jumlah kota sebanyak 18 dari 30 kabupaten/kota. Sedangkan kelompok 2 terdiri atas 12 kota dengan nilai silhouette sebesar 0,53. . Hal itu dapat dilihat dari Clusplot pada Gambar 4. Gambar clusplot 2 -dimensi (clustering plot) dari dua kelompok dan garis merah menunjukkan jarak antar kelompok.

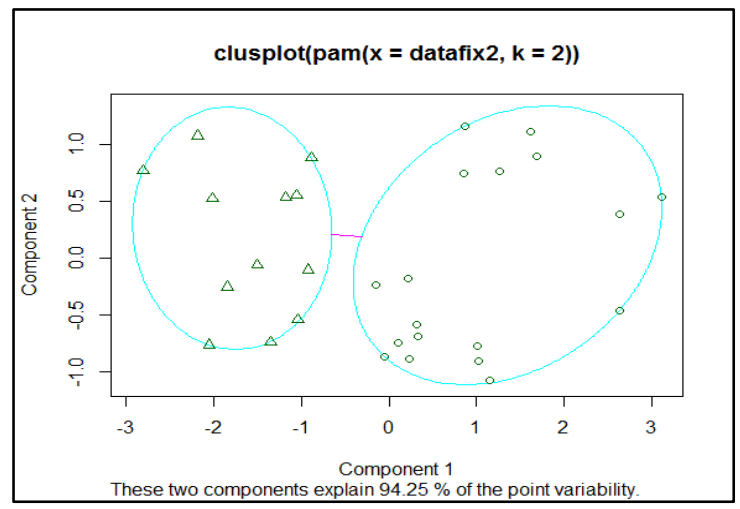

Gambar 4. Clusplot $k=2$

Gambar 5 menunjukkan silhouette plot. Dalam silhouette, $\mathrm{S}_{\mathrm{i}}$ yang besar (hampir 1) menunjukkan bahwa pengamatan yang sesuai terklompok sangat baik, $S_{\mathrm{i}}$ yang besar (hampir 0) berarti pengamatan terletak di antara dua kelompok, dan pengamatan dengan $S_{i}$ negatif mungkin ditempatkan di kelompok yang salah.

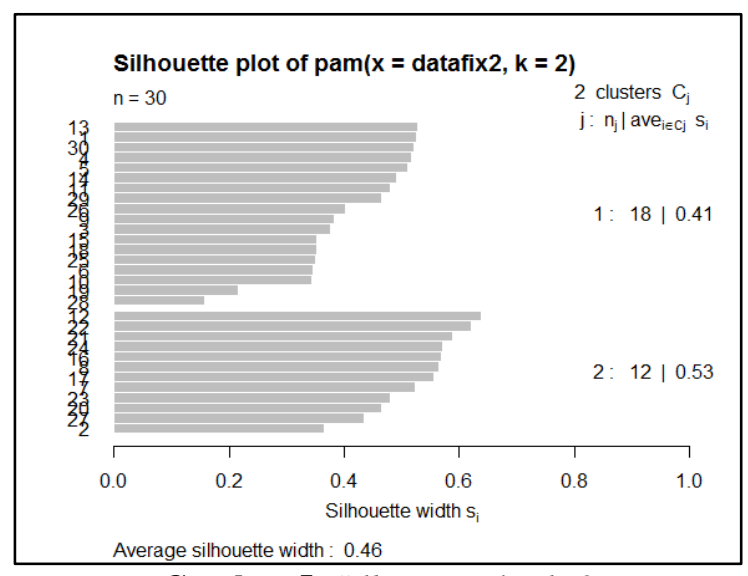

Gambar 5. Silhouette Plot $k=2$

Anggota kelompok untuk metode $k$-medoid dengan nilai $k=2$ ditunjukkan pada Tabel 2 . 
Tabel 2 Hasil Kelompok Metode $k$-medoid berdasarkan nilai Silhouette

\begin{tabular}{llc}
\hline Kelompok & Anggota Kelompok & Jumlah \\
\hline Kelompok & Kabupaten/Kota : Selayar, Bantaeng, Jeneponto, Takalar, Gowa, Pangkep, Barru, Bone, & 18 \\
1 & Wajo, Sidrap, Pinrang, Tana Toraja, Luwu Utara, Majene, Polewali Mandar, Mamuju, & \\
& Mamuju Utara, dan Mamuju Tengah. & \\
Kelompok & Kabupaaten/Kota: Bulukumba, Sinjai, Maros, Soppeng, Enrekang, Luwu, Luwu Tmur, & 12 \\
2 & Toraja Utara, Makassar, Pare-pare, Palopo, dan Mamasa. & \\
\hline
\end{tabular}

\subsubsection{Metode K-Medoid dengan nilai $k=3$}

Dengan nilai $k=3$ yang terdiri atas 3 kelompok yaitu kelompok 1 terdiri dari 8 kabupaten/kota yang nilai silhouettenya sebesar 0,29. Kemudian kelompok 2 dengan silhouette 0,42 terdiri atas 12 kabupaten/kota. Dan untuk kelompok 3 terdiri atas 10 kabupaten/kota dengan nilai silhouette sebesar 0,62. Pengelompokan terbentuk dikarenakan adanya persamaan nilai jarak dari masing-masing kabupaten/kota tersebut dalam satu kelompok. Hal itu dapat dilihat dari Clusplot dan Silhouette plot. Gambar 6 adalah clusplot 2 -dimensi (clustering plot) dari tiga kelompok dan garis merah menunjukkan jarak antar kelompok.

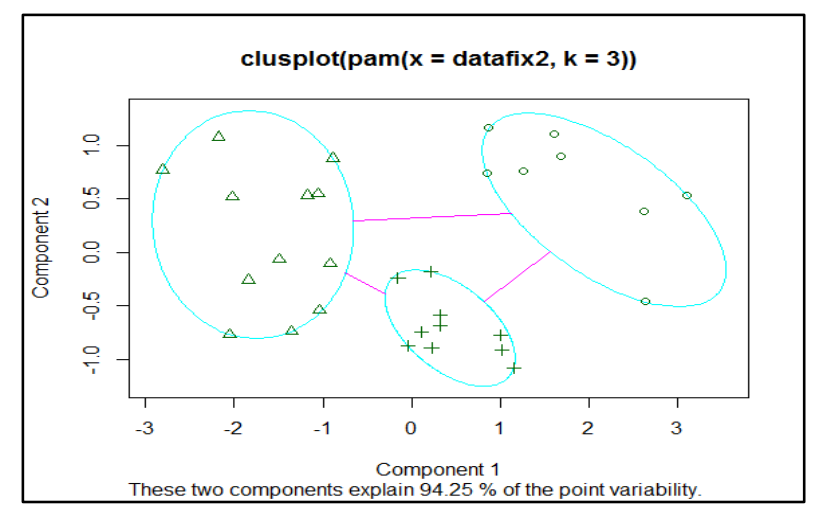

Gambar 6. Clusplot $k=3$

Gambar 7 menunjukkan silhouette plot. Dalam silhouette, $\mathrm{S}_{\mathrm{i}}$ yang besar (hampir 1) menunjukkan bahwa pengamatan yang sesuai terkelompok sangat baik, $S_{i}$ yang besar (hampir 0) berarti pengamatan terletak di antara dua kelompok, dan pengamatan dengan $S_{i}$ negatif mungkin ditempatkan di kelompok yang salah.

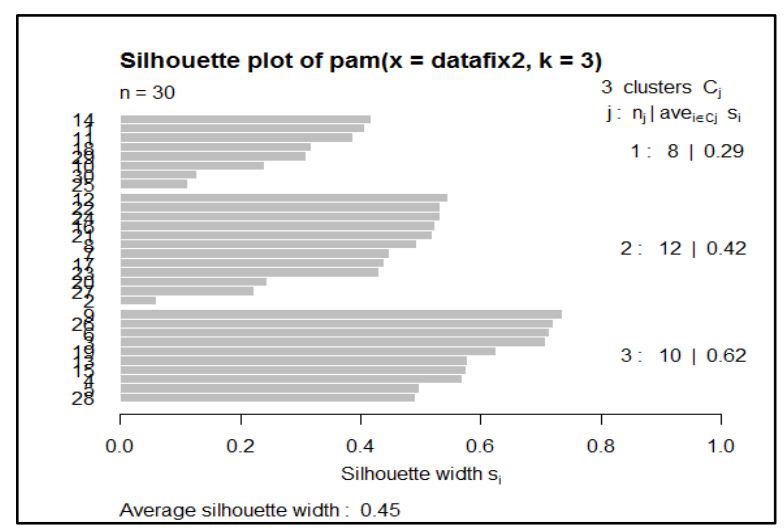

Gambar 7. Silhouette Plot $k=3$

Tabel 3 menjelaskan anggota kelompok untuk metode $k$-medoid dengan nilai $k=3$. 
Tabel 3.3. Hasil Kelompok Metode $k$-medoid berdasarkan nilai Silhouette

\begin{tabular}{lll}
\hline Kelompok & Anggota Kelompok & Jumlah \\
\hline Kelompok 1 & Kabupaten/Kota : Sidarap, Selayar, Bone, Tana Toraja, 8 \\
& Mamuju Utara, Barru, Mamju Tengah, dan Majene. & \\
Kelompok 2 & Kabupaaten/Kota : Soppeng, Makassar, Palopo, Enrekang, 12 \\
& Toraja Utara, Maros, Sinjai, Luwu, Pare-pare, Luwu Timur, \\
& Mamasa, Bulukumba. \\
Kabupaaten/Kota : Pangkep, Polewali Mandar, Gowa, 10 \\
Kantaeng, Luwu Utara, Wajo, Pinrang, Jeneponto, Takalar, \\
dan Mamuju.
\end{tabular}

\subsubsection{Metode $K$-Medoid dengan nilai $k=4$}

Nilai $\mathrm{k}=4$ berdasarkan nilai silhouette sebesar 0,49 terdiri atas 4 kelompok yaitu kelompok 1, kelompok 2, kelompok 3, dan kelompok 4 dengan anggota setiap kelompok ditunjukkan pada Gambar 4.11 dan Gambar 3.8. Kelompok 1 memiliki nilai silhouette sebesar 0,51 yang terdiri atas 3 kabupaten/ kota. Sementara untuk kelompok 2 terdiri atas 12 kabupaten/ kota dengan nilai silhouette sebesar 0,41. Kemudian untuk kelompok 3 dengan nilai silhouette sebesar 0,60 terdiri dari 10 kabupaten/kota. Dan kelompok 4, terdiri dari 5 kabupaten/kota dengan nilai silhouette sebesar 0,44 .

Empat kelompok terbentuk dikarenakan adanya persamaan nilai jarak dari masing-masing kabupaten/kota tersebut dalam satu kelompok. Hal itu dapat dilihat dari Clusplot dan Silhouette. Gambar 8 adalah clusplot 2-dimensi (clustering plot) dari empat kelompok dan garis merah menunjukkan jarak antar kelompok.

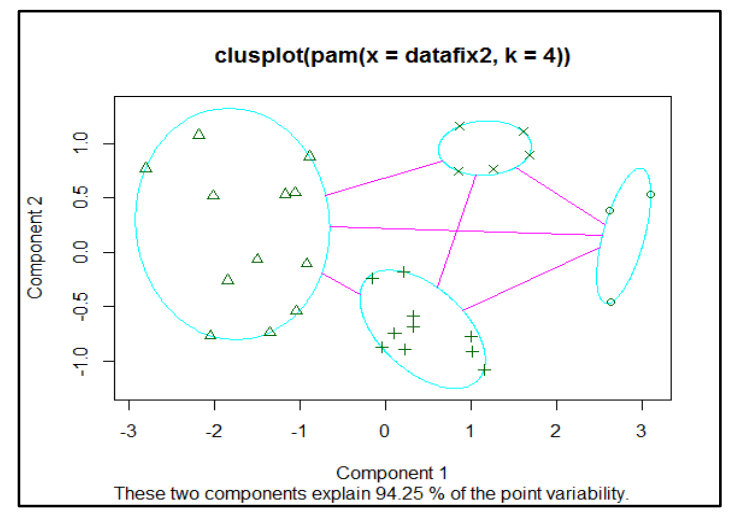

Gambar 8. Clusplot $k=4$

Gambar 3.9 menunjukkan silhouette Plot. Dalam silhouette, $\mathrm{S}_{\mathrm{i}}$ yang besar (hampir 1) menunjukkan bahwa pengamatan yang sesuai terkelompok sangat baik, $S_{i}$ yang besar (hampir 0 ) berarti pengamatan terletak di antara dua kelompok, dan pengamatan dengan $S_{i}$ negatif mungkin ditempatkan di kelompok yang salah.

Selanjutnya anggota kelompok untuk metode $k$-medoid dengan nilai $k=4$. Terlihat bahwa kelompok 1 terdiri atas 3 kabupaten/ kota, kelompok 2 terdiri atas 12 kabupaten/ kota, kelompok 3 terdiri atas 10 kabupaten/ kota dan kelompok 4 terdiri atas 5 kabupaten/kota. Selengkapnya dapat dilihat di tabel 4.

Tabel 4. Hasil Kelompok Metode $k$-medoid berdasarkan nilai Silhouette

\begin{tabular}{lll}
\hline Kelompok & Anggota Kelompok & Jumlah \\
\hline Kelompok 1 & Kabupaaten/Kota : Bone, Selayar, dan Mamuju Tengah. & 3 \\
Kelompok 2 & Kabupaaten/Kota : Soppeng, Makassar, Palopo, Enrekang, Toraja & 12 \\
& Utara, Maros, Sinjai , Luwu, Pare-pare, Luwu Timur, Mamasa, & \\
& dan Bulukumba.
\end{tabular}




\begin{tabular}{lll}
\hline Kelompok & Anggota Kelompok & Jumlah \\
\hline Kelompok 3 & $\begin{array}{l}\text { Kabupaaten/Kota : Pangkep, Gowa, Polewali Mandar, Bantaeng, } \\
\text { Luwu Utara, Wajo, Jenepnto, Mamuju, Pinrang, dan Takalar. } \\
\text { Kelompok 4 } \\
\text { Kabupaaten/Kota : Mamuju Utara, Barru, Majene, Tana Toraja, 5 } \\
\text { dan Sidrap. }\end{array}$ \\
\hline
\end{tabular}

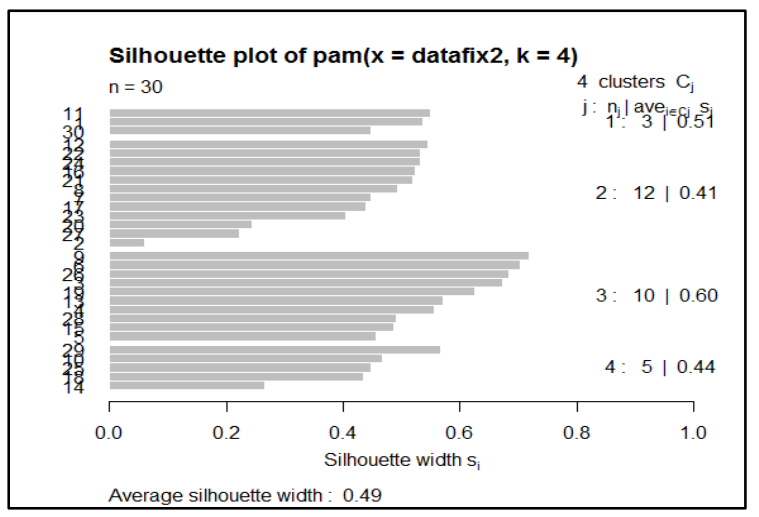

Gambar 9. Silhouette Plot $k=4$

\subsubsection{Metode K-Medoid dengan nilai $k=5$}

Untuk nilai $k=5$ berdasarkan nilai silhouette sebesar 0,4 terdiri dari 5 kelompok. Dimana kelompok 1, kelompok 2, kelompok 3, kelompok 4, dan kelompok 5 dengan anggota setiap kelompok dan nilai silhouette masing-masing kelompok ditunjukkan pada Gambar 10 dan Gambar 11. Dan lima kelompok terbentuk dikarenakan adanya persamaan nilai jarak dari masing-masing kabupaten/kota tersebut dalam satu kelompok. Hal itu dapat dilihat dari Clusplot dan silhouette. Gambar 3.10 adalah clusplot 2-dimensi (clustering plot) dari dua kelompok dan garis merah menunjukkan jarak antar kelompok.

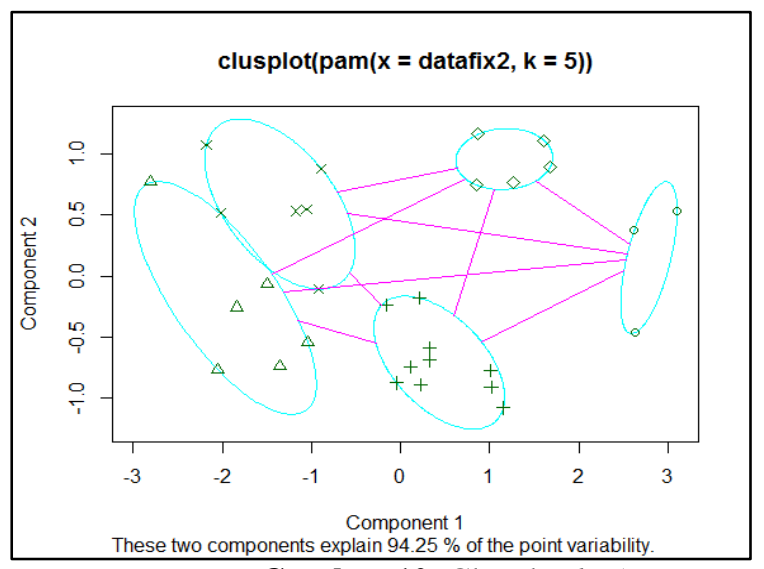

Gambar 10. Clusplot $k=5$

Gambar 11 menunjukkan silhouette plot. Dalam silhouette, $\mathrm{S}_{\mathrm{i}}$ yang besar (hampir 1) menunjukkan bahwa pengamatan yang sesuai terkelompok sangat baik, $S_{i}$ yang besar (hampir 0) berarti pengamatan terletak di antara dua kelompok, dan pengamatan dengan $S_{i}$ negatif mungkin ditempatkan di kelompok yang salah. Pada Silhouette plot terlihat adanya kabupaten/ kota di kelompok dua dan kelompok empat ukuran jarak silhouettenya memiliki nilai jarak negatif sehingga pengelompokan yang terbaik sesuai dengan nilai silhouette terbesar yaitu pada $\mathrm{k}=4$. 


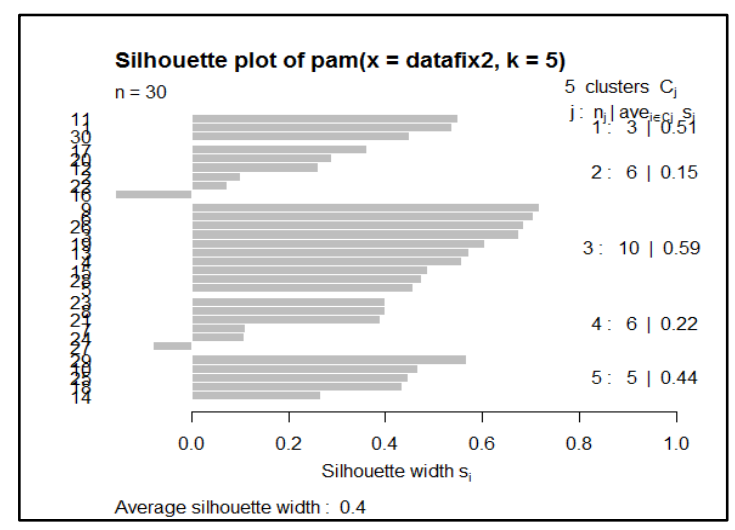

Gambar 11. Silhouette Plot $k=5$

Metode $k$-medoid dengan nilai $k=5$ dengan anggota kelompok ditunjukkan pada Tabel 5 .

Tabel 3.5. Hasil Kelompok Metode $k$-medoid berdasarkan nilai Silhouette

\begin{tabular}{llc}
\hline Kelompok & \multicolumn{1}{c}{ Jumlah } \\
\hline Kelompok 1 & \multicolumn{1}{c}{ Anggota Kelompok } & 3 \\
Kelompok 2 & $\begin{array}{l}\text { Kabupaten/Kota : Bone, Selayar, dan Mamuju Tengah } \\
\text { Makassar, dan Enrekang. } \\
\text { Kabupaten/Kota : Pangkep, Gowa, Polewali Mandar, Bantaeng, } \\
\text { Kelompok 3 }\end{array}$ & 10 \\
Kelompu Utara, Wajo, Jeneponto, Pinrang, Mamuju, dan Takalar. & $\begin{array}{l}\text { Kabupaten/ Kota : Pare-pare, Maros, Toraja Utara, Sinjai, Palopo, } \\
\text { dan Mamasa. } \\
\text { Kabupaten/Kota : Mamuju Utara, Barru, Majene, Tana Toraja, dan } \\
\text { Kelompok 5 }\end{array}$ & 6 \\
\hline
\end{tabular}

Hasil pengelompokkan nilai $k=5$ dengan jumlah daerah terbanyak pada kelompok 3 sebanyak 10 daerah. Sementara jumlah daerah terkecil pada kelompok 1 sebanyak 3 daerah.

Tabel 6. Nilai Silhouette Metode k-medoid

\begin{tabular}{cc}
\hline Nilai $k$ & Nilai Sillhoutte \\
\hline$k=2$ & 0,46 \\
$k=3$ & 0,45 \\
$k=4$ & 0,49 \\
$k=5$ & 0,40 \\
\hline
\end{tabular}

Adapun karakteristik hasil kelompok metode $k$-medoid yang terbaik berdasarkan nilai silhouette terbesar yaitu nilai $k$ $=4$ dapat dilihat pada tabel 6. Nilai Sillhouette Metode $k$-medoid dilakukan sesuai dengan indikator Angka Partisipasi Pendidikan. Karakteristik pengelompokan dengan $k=4$ dapat dilihat pada Tabel 7. Banyaknya kabupaten/kota dalam setiap kelompok.

Tabel 3.7. Karakteristik pengelompokkan $k$-medoid dengan $k=4$

\begin{tabular}{ccccccc}
\hline$M$ & $\begin{array}{c}\text { ID } \\
\text { medoid }\end{array}$ & $\begin{array}{c}\text { Rataan } \\
\text { APS }\end{array}$ & $\begin{array}{c}\text { Rataan } \\
\text { APK }\end{array}$ & $\begin{array}{c}\text { Rataan } \\
\text { APM }\end{array}$ & $\begin{array}{c}\text { Banyakya } \\
\text { daerah }\end{array}$ & $\begin{array}{c}\text { Rataan } \\
\text { Nilai APP }\end{array}$ \\
\hline 1 & 1 & 58,95 & 68,65 & 50,11 & 3 & 59,24 \\
2 & 21 & 79,14 & 83,61 & 63,72 & 12 & 75,49 \\
3 & 26 & 65,75 & 83,98 & 57,37 & 10 & 69,03 \\
4 & 29 & 68,89 & 72,71 & 54,20 & 5 & 65,27 \\
\hline
\end{tabular}

Ket: $m=$ nomor kelompok 
Berdasarkan Tabel 3.7. Menjelaskan bahwa karakteristik hasil pengelompokan metode $k$-medoid dengan $\mathrm{k}=4$ yang diperoleh adalah sebagai berikut:

a. Kelompok 1

Kelompok 1 merupakan kelompok yang beranggotakan 3 daerah dari 30 kabupaten/kota. Berdasarkan peubah numerik (Tabel 3.7), kelompok tersebut memiliki nilai rata-rata APS 58,95\%, nilai rata-rata APK 68,65\%, nilai rata-rata APM 50,11\% .dengan rata-rata nilai APP 59,24\% dapat dikategorikan rendah. Selain itu pusat median terletak di kabupaten/kota 1 yaitu kabupaten Selayar.

b. Kelompok 2

Kelompok 2 merupakan kelompok yang beranggotakan 12 daerah dari 30 kabupaten/kota. Berdasarkan peubah numerik (Tabel 3.7), kelompok tersebut memiliki nilai APS 79,14\%, nilai rata-rata APK 83,61\%, dan nilai ratarata APM 63,72\% .dengan rata-rata nilai APP 75,49\% dapat dikatgorikan sangat tinggi. Selain itu pusat median terletak di kabupaten/kota 21 yaitu kabupaten Luwu Timur.

c. Kelompok 3

Kelompok 3 merupakan kelompok yang beranggotakan 10 daerah dari 30 kabupaten/kota. Berdasarkan peubah numerik (Tabel 3.7), kelompok tersebut memiliki nilai rata-rata APS 65,75\%, nilai rata-rata APK 83,98\%, nilai rata-rata APM 57,73\% dengan rata-rata nilai APP 69,03\% dapat dikatgorikan tinggi. Selain itu pusat median terletak di kabupaten/kota 26 yaitu kabupaten Majene.

d. Kelompok 4

Kelompok 1 merupakan kelompok yang beranggotakan 18 daerah dari 30 kabupaten/kota. Berdasarkan peubah numerik (Tabel 3.7), kelompok tersebut memiliki nilai rata-rata APS 68,89\%, nilai rata-rata APK 72,71\%, nilai rata-rata APM 54,20\% .dengan rata-rata nilai APP 65,27\% dapat dikatgorikan sedang. Selain itu pusat median terletak di kabupaten/kota 29 yaitu kabupaten Mamuju.

Pengelompokan pada metode $k$-medoid diawali dengan menemukan sejumlah $k$ objek (disebut sebagai objek representatif atau medoid) yang posisinya berada pada pusat data. Salah satu pendekatannya yaitu dengan mencari sejumlah obyek yang meminimumkan rata-rata jarak terdekat antara objek representatif dengan objek lain.

\subsection{Pengelompokan dengan Metode CLARA}

Hasil pengelompokan dengan menggunakan metode CLARA pada Indikator Angka Partiispasi Pendidikan menggunakan algoritma CLARA adalah nilai $k=2$ hingga nilai $k=5$, meghasilkan kelompok terbaik yaitu $k=4$.

\subsubsection{Metode CLARA dengan nilai $k=2$}

Pengelompokan berdasarkan metode CLARA dengan nilai $k=2$. Dimana kelompok 1 memiliki nilai silhouette sebesar 0,41 dengan jumlah kota sebanyak 18 dari 30 kabupaten/kota. Sedangkan kelompok 2 terdiri atas 12 kota dengan nilai silhouette sebesar 0,53. Kedua kelompok terbentuk dikarenakan adanya persamaan nilai jarak dari masing-masing kabupaten/kota tersebut dalam satu kelompok. Dimana jarak yang digunakan dalam metode CLARA ini yaitu jarak Euclidean, sama halnya pada metode k-medoid. Hal itu dapat dilihat dari Clusplot dan silhouette plot. Gambar 12 adalah clusplot 2 -dimensi (clustering plot) dari dua kelompok dan garis merah menunjukkan jarak antar kelompok.

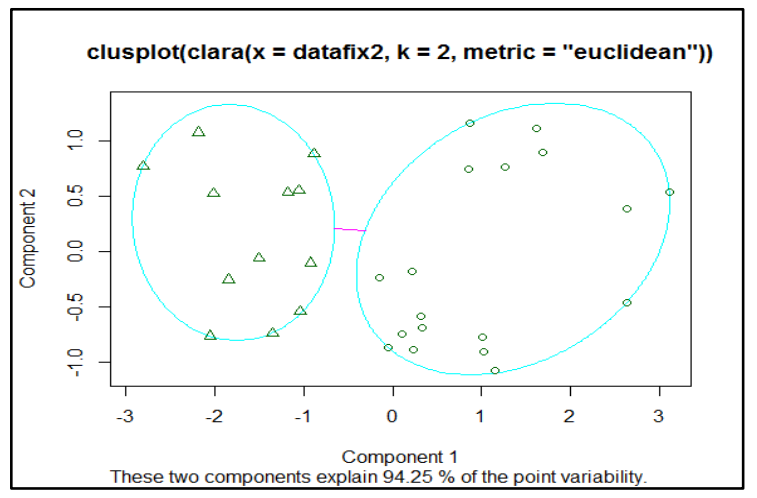

Gambar 12. Clusplot $k=2$ 
Gambar 13 menunjukkan silhouette. Dalam silhouette, $\mathrm{S}_{\mathrm{i}}$ yang besar (hampir 1) menunjukkan bahwa pengamatan yang sesuai terkelompok sangat baik, $S_{i}$ yang besar (hampir 0 ) berarti pengamatan terletak di antara dua kelompok, dan pengamatan dengan $S_{i}$ negatif mungkin ditempatkan di kelompok yang salah.

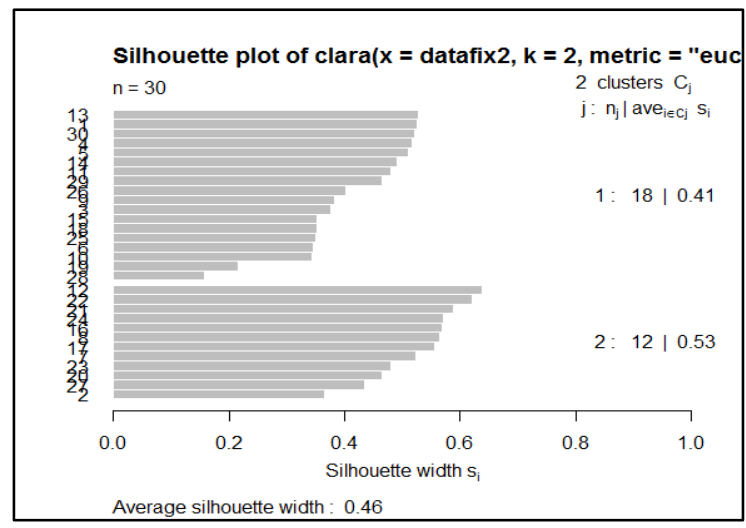

Gambar 13. Silhouette Plot $k=2$

Berikut ini adalah tabel anggota kelompok untuk metode CLARA dengan nilai $k=2$ ditunjukkan pada Tabel 3.8. Hasil pengelompokkan dengan $\mathrm{k}=2$ menghasilkan jumlah daerah di kelompok 1 sebanyak 18 daerah, sedangkan kelompok 2 sebanyak 12 daerah. Secara lebih rinci daerah tersebut dapa dilihat tabel 8.

Tabel 4.8. Hasil Kelompok Metode CLARA berdasarkan nilai Silhouette

\begin{tabular}{llc}
\hline Kelompok & \multicolumn{1}{c}{ Anggota Kelompok } & Jumlah \\
\hline Kelompok 1 & Kabupaten/Kota : Selayar, Bantaeng, Jeneponto, Takalar, Gowa, & 18 \\
& Pangkep, Barru, Bone, Wajo, Sidrap, Pinrang, Tana Toraja, Luwu & \\
& Utara, Majene, Polewali Mandar, Mamuju, Mamuju Utara, dan & \\
& Mamuju Tengah. & 12 \\
Kelompok 2 & Kabupaaten/Kota: Bulukumba, Sinjai, Maros, Soppeng, & \\
& Enrekang, Luwu, Luwu Tmur, Toraja Utara, Makassar, \\
& Pare-pare, Palopo, dan Mamasa. & \\
\hline
\end{tabular}

\subsubsection{Metode CLARA dengan nilai $k=3$}

Dengan nilai $k=3$ yang terdiri atas 3 kelompok yaitu kelompok 1 terdiri dari 8 kabupaten/kota yang nilai silhouettenya sebesar 0,29. Kemudian kelompok 2 dengan silhouette 0.42 terdiri atas 12 kabupaten/kota. Dan untuk kelompok 3 terdiri atas 10 kabupaten/kota dengan nilai silhouette sebesar 0,62. Pengelompokan terbentuk dikarenakan adanya persamaan nilai jarak dari masing-masing kabupaten/kota tersebut dalam satu kelompok. Hal itu dapat dilihat dari Clusplot dan silhouette. Gambar 13 adalah clusplot 2 -dimensi (clustering plot) dari dua kelompok dan garis merah menunjukkan jarak antar kelompok.

Gambar 14 menunjukkan silhouette. Dalam silhouette, $\mathrm{S}_{\mathrm{i}}$ yang besar (hampir 1) menunjukkan bahwa pengamatan yang sesuai terkelompok sangat baik, $S_{i}$ yang besar (hampir 0 ) berarti pengamatan terletak di antara dua kelompok, dan pengamatan dengan $S_{i}$ negatif mungkin ditempatkan di kelompok yang salah. Selain itu garis merah pada clusplot menunjukkan jarak antar kelompok.

Tabel 9 menjelaskan anggota kelompok untuk metode CLARA dengan nilai $k=3$. 
Tabel 9. Hasil Kelompok Metode CLARA berdasarkan nilai Silhouette

\begin{tabular}{llc}
\hline Kelompok & \multicolumn{1}{c}{ Anggota Kelompok } & Jumlah \\
\hline Kelompok 1 & Kabupaten/Kota : Sidarap, Selayar, Bone, Tana Toraja, Mamuju & 8 \\
Kelompok 2 & Utara, Barru, Mamju Tengah, dan Majene. & \\
& Kabupaaten/Kota : Soppeng, Makassar, Palopo, Enrekang, Toraja & 12 \\
& Utara, Maros, Sinjai, Luwu, Pare-pare, Luwu Timur, Mamasa, & \\
Bulukumba. & \multirow{2}{*}{$\begin{array}{l}10 \\
\text { Kelompok 3 }\end{array}$} \\
& Lubupaaten/Kota : Pangkep, Polewali Mandar, Gowa, Bantaeng, & \\
\hline
\end{tabular}

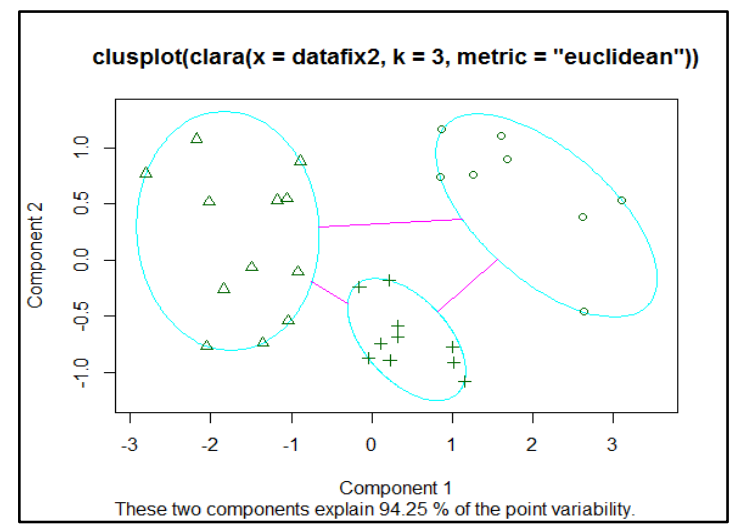

Gambar 13. Clusplot $k=3$

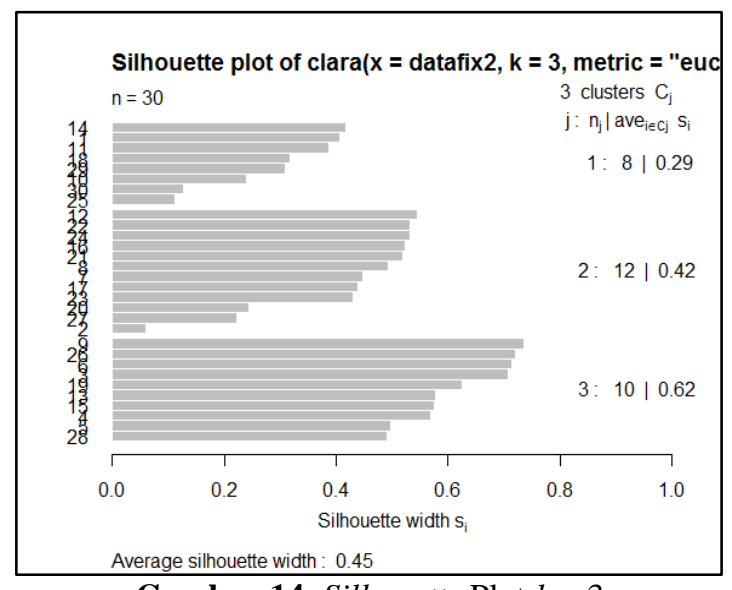

Gambar 14. Silhouette Plot $k=3$

Hasil pengelompokan terbaik pada metode $k$-medoid adalah pengelompokan dengan nilai $k=4$. Pengelompokan CLARA sebagai metode pengembangan dari k-medoid dilakukan dengan inisiasi banyaknya kelompok berdasarkan Indikator Angka Partisipasi Pendidikan.

\subsubsection{Metode CLARA dengan nilai $k=4$}

Nilai $\mathrm{k}=4$ berdasarkan nilai silhouette sebesar 0,488 terdiri atas 4 kelompok yaitu kelompok 1, kelompok 2, kelompok 3, dan kelompok 4.

Kelompok 1 memiliki nilai silhouette sebesar 0,511 yang terdiri atas 3 kabupaten/kota. Sementara untuk kelompok 2 terdiri atas 12 kabupaten/kota dengan nilai silhouette sebesar 0,413. Kemudian untuk kelompok 3 dengan nilai silhouette sebesar 0,59 terdiri dari 10 kabupaten/ kota. Dan kelompok 4, terdiri dari 5 kabupaten/kota dengan nilai silhouette sebesar 0,436. Hal itu dapat dilihat dari Clusplot dan silhouette Plot. 


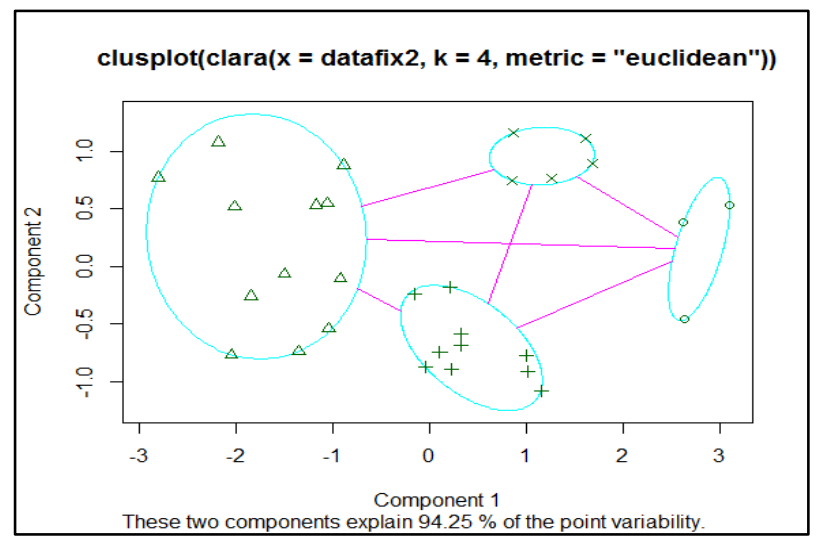

Gambar 15. Clusplot $k=4$

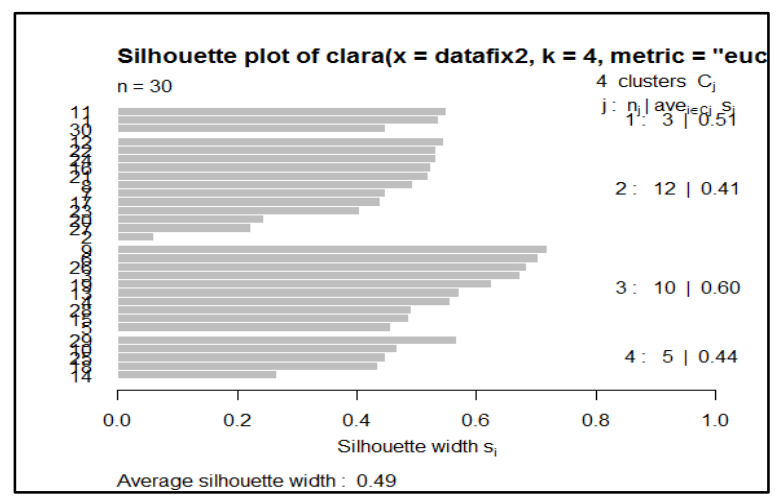

Gambar 16. Silhouette Plot $k=4$

Gambar 16 Silhouette Plot, $S_{\mathrm{i}}$ yang besar (hampir 1) menunjukkan bahwa pengamatan yang sesuai terkelompok sangat baik, $S_{i}$ yang besar (hampir 0) berarti pengamatan terletak di antara dua kelompok, dan pengamatan dengan $S_{i}$ negatif mungkin ditempatkan di kelompok yang salah.

Hasil Pengelompokkan dengan metod CLARA dengan $\mathrm{k}=4$, jumlah masing masing daerah di setiap kelompok dapat dilihat di tabel 10.

Tabel 10. Hasil Kelompok Metode CLARA berdasarkan nilai Silhouette

\begin{tabular}{llc}
\hline Kelompok & \multicolumn{1}{c}{ Anggota Kelompok } & Jumlah \\
\hline Kelompok 1 & Kabupaten/Kota : Bone, Selayar, dan Mamuju Tengah. & 3 \\
Kelompok 2 & Kabupaten/Kota : Soppeng, Makassar, Palopo, Enrekang, \\
& $\begin{array}{l}\text { Toraja Utara, Maros, Sinjai, Luwu, Pare-pare, Luwu } \\
\text { Timur, Mamasa, dan Bulukumba. }\end{array}$ & \\
Kelompok 3 & $\begin{array}{l}\text { Kabupaten/Kota : Pangkep, Gowa, Polewali Mandar, } \\
\text { Bantaeng, Luwu Utara, Wajo, Jeneponto, Mamuju, } \\
\text { Kelompok 4 }\end{array}$ & \\
& $\begin{array}{l}\text { Kabupaten/Kota : Mamuju Utara, Barru, Majene, Tana } \\
\text { Toraja, dan Sidrap. }\end{array}$ & 5 \\
\hline
\end{tabular}

Dan nilai $k=5$ berdasarkan nilai silhouette sebesar 0,4 terdiri dari 5 kelompok. Dimana kelompok 2 memiliki jumlah daerah terbanyak yaitu sebanyak 12 daerah dibandingkan dengan kelompok yang lainnya. 


\subsubsection{Metode CLARA dengan nilai $k=5$}

Lima kelompok terbentuk dikarenakan adanya persamaan nilai jarak dari masing-masing kabupaten/kota tersebut dalam satu kelompok. Hal itu dapat dilihat dari Clusplot dan silhouette pada Gambar 17.

Gambar 17 adalah clusplot 2 -dimensi (clustering plot) dari dua kelompok dan garis merah menunjukkan jarak antar kelompok.

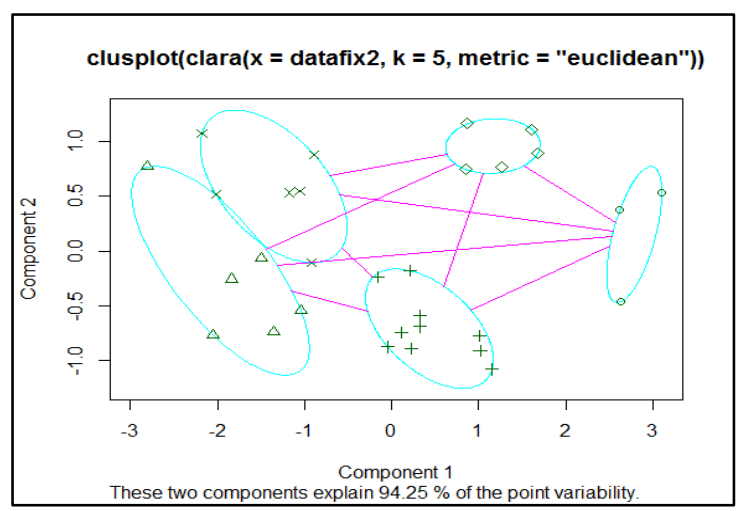

Gambar 17. Clusplot $k=5$

Gambar 18 menunjukkan silhouette. Dalam silhouette, $S_{\mathrm{i}}$ yang besar (hampir 1) menunjukkan bahwa pengamatan yang sesuai terkelompok sangat baik, $S_{i}$ yang besar (hampir 0 ) berarti pengamatan terletak di antara dua kelompok, dan pengamatan dengan $S_{i}$ negatif mungkin ditempatkan di kelompok yang salah. Pada Silhouette plot terlihat adanya kabupaten/ kota yang memiliki nilai jarak yang negatif sehingga pengelompokkan terhenti pada $\mathrm{k}=4$.

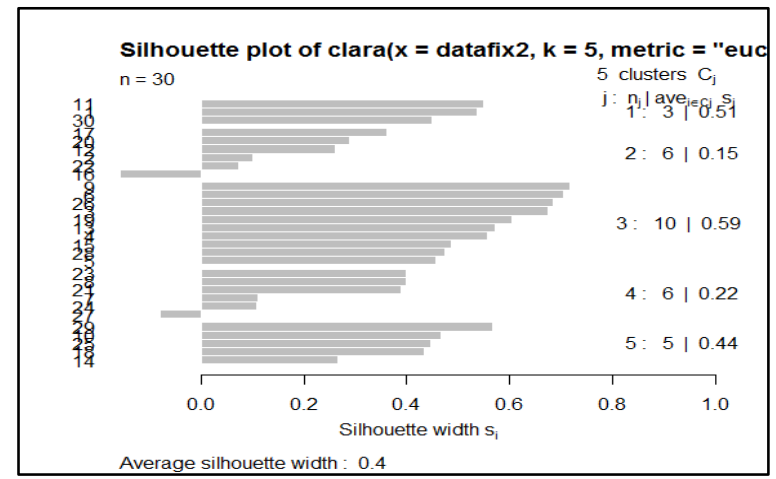

Gambar 18. Silhouette Plot $k=5$

Selanjutnya anggota kelompok untuk metode CLARA dengan nilai $k=5$ ditunjukkan pada Tabel 11.

Tabel 11. Hasil Kelompok Metode CLARA berdasarkan nilai Silhouette

\begin{tabular}{llc}
\hline Kelompok & \multicolumn{1}{c}{ Jumlah } \\
\hline Kelompok 1 & \multicolumn{1}{c}{ Kabupaten/Kota : Bone, Selayar, dan Mamuju Tengah } & 3 \\
Kelompok 2 & $\begin{array}{l}\text { Kabupaten/Kota : Luwu, Luwu Timur, Soppeng, Bulukumba, Makassar, } \\
\text { dan Enrekang. }\end{array}$ & 6 \\
Kelompok 3 & $\begin{array}{l}\text { Kabupaten/Kota : Pangkep, Gowa, Polewali Mandar, Bantaeng, Luwu } \\
\text { Utara, Wajo, Jeneponto, Pinrang, Mamuju, dan Takalar. }\end{array}$ & 10 \\
Kelompok 4 & $\begin{array}{l}\text { Kabupaten/Kota : Pare-pare, Maros, Toraja Utara, Sinjai, Palopo, dan } \\
\text { Mamasa. } \\
\text { Kelompok 5 }\end{array}$ & $\begin{array}{l}6 \\
\text { Kabupaten/Kota : Mamuju Utara, Barru, Majene, Tana Toraja, dan }\end{array}$ \\
\hline
\end{tabular}


Adapun karakteristik hasil kelompok metode CLARA yang terbaik berdasarkan nilai silhouette terbesar yaitu nilai $k=$ 4 dapat dilihat pada Tabel 12. Analisis kelompok menggunakan CLARA dengan $k=4$ yang merupakan hasil kelompok yang paling baik dengan nilai rataan Angka Partisipasi Pendidikan yang sangat besar dari rataan kelompok lain. Banyaknya kabupaten dan kota.

Tabel 12. Nilai Sillhoutte Metode CLARA

\begin{tabular}{c|c}
\hline Nilai $k$ & Nilai Silhouette \\
\hline$k=2$ & 0,46 \\
$k=3$ & 0,45 \\
$k=4$ & 0,49 \\
$k=5$ & 0,40 \\
\hline
\end{tabular}

Adapun karakteristik hasil kelompok metode CLARA yang terbaik berdasarkan nilai silhouette terbesar yaitu nilai $k=$ 4 dapat dilihat pada tabel 3.12. Nilai Silhouette Metode CLARA dilakukan sesuai dengan indikator Angka Partisipasi Pendidikan. Karakteristik pengelompokan dengan $k=4$ dapat dilihat pada Tabel 13. Banyaknya kabupaten/kota dalam setiap kelompok.

Tabel 13. Karakteristik pengelompokkan CLARA dengan $k=4$

\begin{tabular}{ccccccc}
\hline m & ID Medoid & Rataan APS & Rataan APK & Rataan APM & Banyaknya daerah & Rataan Nilai APP \\
1 & 1 & 58,95 & 68,65 & 50,11 & 3 & 59,24 \\
2 & 21 & 79,14 & 83,61 & 63,72 & 12 & 75,49 \\
3 & 26 & 65,75 & 83,98 & 57,37 & 10 & 69,03 \\
4 & 29 & 68,89 & 72,71 & 54,20 & 5 & 65,27 \\
\hline
\end{tabular}

Ket: $m=$ nomor kelompok

Berdasarkan Tabel 13, menjelaskan bahwa karakteristik hasil pengelompokan metode CLARA dengan $k=4$ yang diperoleh adalah sebagai berikut:

a. Kelompok 1

Kelompok 1 merupakan kelompok yang beranggotakan 3 daerah dari 30 kabupaten/kota. Berdasarkan peubah numerik (Tabel 3.13), kelompok tersebut memiliki nilai rata-rata APS 58,95\%, nilai rata-rata APK 68,65\% , nilai rata-rata APM 50,11\% .dengan rata-rata nilai APP 59,24\% dapat dikategorikan rendah. Selain itu pusat median terletak di kabupaten/ kota 1 yaitu kabupaten Selayar.

b. Kelompok 2

Kelompok 2 merupakan kelompok yang beranggotakan 12 daerah dari 30 kabupaten/kota. Berdasarkan peubah numerik (Tabel 3.13), kelompok tersebut memiliki nilai APS 79,14\%, nilai rata-rata APK 83,61\%, dan nilai rata-rata APM 63,72\% .dengan rata-rata nilai APP 75,49\% dapat dikatgorikan sangat tinggi. Selain itu pusat median terletak di kabupaten/ kota 21 yaitu kabupaten Luwu Timur.

c. Kelompok 3

Kelompok 3 merupakan kelompok yang beranggotakan 10 daerah dari 30 kabupaten/kota. Berdasarkan peubah numerik (Tabel 3.13), kelompok tersebut memiliki nilai rata-rata APS 65,75\%, nilai rata-rata APK 83,98\%, nilai rata-rata APM 57,73\% .dengan rata-rata nilai APP 69,03\% dapat dikatgorikan tinggi. Selain itu pusat median terletak di kabupaten/ kota 26 yaitu kabupaten Majene.

d. Kelompok 4

Kelompok 1 merupakan kelompok yang beranggotakan 18 daerah dari 30 kabupaten/kota. Berdasarkan peubah numerik (Tabel 3.13), kelompok tersebut memiliki nilai rata-rata APS $68,89 \%$, nilai rata-rata APK 72,71\%, nilai rata-rata APM 54,20\% .dengan rata-rata nilai APP 65,27\% dapat dikatgorikan sedang. Selain itu pusat median terletak di kabupaten/ kota 29 yaitu kabupaten Mamuju.

Pengelompokan pada metode CLARA diawali dengan menemukan sejumlah $k$ objek (disebut sebagai objek representatif atau medoid) yang posisinya berada pada pusat data. Salah satu pendekatannya yaitu dengan mencari sejumlah objek yang meminimumkan rata-rata jarak terdekat antara objek representatif dengan objek lain. 
Dari kedua metode $k$-medoid dan CLARA memiliki nilai silhouette yang sama, sehingga tidak dapat ditentukan metode mana yang terbaik karena data yang digunakan sedikit yaitu 30 sampel dan kelompok terbaik berdasarkan nilai silhouettenya yaitu 0,49 dengan nilai $k=4$ yang memiliki anggota kabupaten/kota yang sama disetiap kelompok yang terbentuk. Namun berdasarkan standar nilai koefisien silhouette dikatakan suatu kelompok baik menurut Lewis (2010), ketika nilai rata-rata rentang koefisien silhouettenya (SC) $>0,51$ menunjukkan bahwa struktur hasil pengelompokan sudah dianggap baik, sedangkan rata-rata rentang koefisien silhouette objek secara keseluruhan $(S C)>0,71$ menunjukkan bahwa struktur hasil pengelompokan sangat baik. Sehingga kelompok yang terbaik adalah 4 kelompok namun bukan kelompok yang terbaik berdasarkan standar nilai koefisien metode $k$-medoid dan CLARA. Penggunaan metode $k$-medoid dan CLARA dalam penelitian kami gunakan tidak optimum untuk mengelompokan dengan ukuran data yang kecil. Tidak seperti pada penelitian Rizky Amalia Firda yang menggunakan data IPM tahun 2015 kabupaten/kota di Indonesia dengan metode $k$-medoid dan CLARA dan tesis dari (Mia Syafrina, 2015) yang menggerombolkan daerah di Indonesia menggunakan metode Fuzzy $k$-rataan dan $k$-medoid.

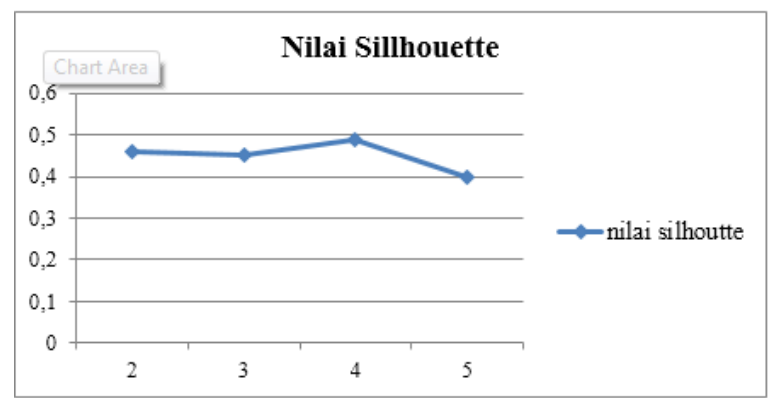

Gambar 19. Nilai koefisien silhouette pada kelompok terbentuk dengan $k$-medoid dan CLARA

Gambar 19 menunjukkan pengelompokan dengan nilai koefisien silhouette terbesar adalah pengelompokan dengan $k$ $=4$. Nilai koefisien silhouette pada $k=4$ adalah 0,49 . Penentuan jumlah kelompok yang dibentuk berdasarkan nilai silhouette, akan berhenti ketika nilai jarak dari masing-masing objek dalam kelompok bernilai negatif. Hal tersebut dapat dilihat pada pengelompokan dengan $k=5$. Nilai Silhouette pada masing-masing metode $k$-medoid dan CLARA dapat dilihat secara lebih rinci pada Tabel 14.

Tabel 14. Nilai Silhouette pada Metode $k$-medoid dan CLARA

\begin{tabular}{ccc}
\hline \multirow{2}{*}{ Nilai $k$} & \multicolumn{2}{c}{ Nilai Silhouette } \\
\cline { 2 - 3 } & $k$-medoid & CLARA \\
\hline$k=2$ & 0,46 & 0,46 \\
$k=3$ & 0,45 & 0,45 \\
$k=4$ & 0,49 & 0,49 \\
$k=5$ & 0,40 & 0,40 \\
\hline
\end{tabular}

\section{Kesimpulan}

Berdasarkan hasil dan pembahasan yang dilakukan untuk mengelompokkan kabupaten/kota di Provinsi Sulawesi Selatan dan Sulawesi Barat dengan Indikator Angka Partisipasi Pendidikan diperoleh kesimpulan:

1. Pengelompokan menggunakan Indikator Angka Partisipasi Pendidikan Provinsi Sulawesi Selatan dan Sulawesi Barat tahun 2017 dengan analisis $K$-Medoid dan CLARA menghasilkan nilai dan jumlah setiap kelompok sama sehingga tidak ada perbedaan diantara kedua metode.

2. Hasil pengelompokan Kabupaten/Kota di Provinsi Sulawesi Selatan dan Sulawesi Barat berdasarkan kategori nilai Angka Partisipasi Pendidikan terdiri atas 4 kelompok. Kelompok 1 terdiri atas Kabupaaten/Kota Bone, Selayar, dan Mamuju Tengah. Selanjutnya kelompok 2 diantaranya Soppeng, Makassar, Palopo, Enrekang, 
Toraja Utara, Maros, Sinjai , Luwu, Pare-pare, Luwu Timur, Mamasa, dan Bulukumba. Kelompok 3 terdiri atas Kabupaaten/Kota Pangkep, Gowa, Polewali Mandar, Bantaeng, Luwu Utara, Wajo, Jenepnto, Mamuju, Pinrang, dan Takalar. Dan kelompok 4 terdiri atas Mamuju Utara, Barru, Majene, Tana Toraja, dan Sidrap.

3. Pengelompokan Kabupaten/Kota di Provinsi Sulawesi Selatan dan Sulawesi Barat berdasarkan kategori nilai Angka Partisipasi Pendidikan terdiri atas 4 kelompok namun kelompok tersebut kurang optimun untuk dikatakan kelompok terbaik berdasarkan standar nilai silhouette.

\section{References}

Agresti, A. (2002). Categorial data analysis (second ed.). New York: John Wiley \& Sond, Inc

Alsulaiman ET. (2013). Classifying Technical Indicators Using K-Medoid Clustering. Journal of Trading 8(2): 2939.

Badan Pusat Statistik. 2017. Indikator Kesejahteraan Rakyat Sulawesi Selatan 2017. Badan Pusat Statistik Provinsi Sulawesi Selatan.

Badan Pusat Statistik. (2017). Statistik Pendidikan Sulawesi Selatan 2017. Badan Pusat Statistik Provinsi Sulawesi Selatan.

Badan Pusat Statistik. (2018). Statistik Daerah Sulawesi Barat 2018. Badan Pusat Statistik Provinsi Sulawesi Barat.

Badan Pusat Statistik. (2012). Statistik Pendidikan Jawa Tengah 2012. Badan Pusat Statistik Provinsi Jawa Tengah.

Badan Perencanaan Pembangunan Nasional. (2015). Seri Analisis Pembangunan Wilayah Provinsi Jawa Timur 2015.

Bolshakova, N., \& Azuaje, F. (2001). Improving Expression Data Mining through Cluster Validity. Departement of Computer Science. Ireland: Trinity College Dublin.

Bunkers M.J., \& J.R. Miller. (1996). Definition of Climate Regions in the Northern Plains Usingan Objective Cluster Modification Technique. Journal of Climate, No. 9, hal 130-146.

Chu, S., John F. Roddick, J.S. Pan (2002). Efficient K-Medoids Algorthms Using Multi-Centroids With Multi-Runs Sampling Scheme. http://citeseer.nj.nec.com/537999..html.

Dewanti. (2013). Perbandingan Metode Cluster validity pada jenis data numeric dan kategori [Skripsi]. Bogor: Institut Pertanian.

Furqon, Muhammad Tanzil, Lailil Muflikhakh.2016. Clustering the potentialrisk of tsunami using DensityBasedSpatial clustering of application withnoise (DBSCAN). Journal ofEnvironmental Engineering \& SustainableTechnology (JEEST) Vol. 03 No. 01, July2016, Pages 1-8.

Hair, JF, Black W.C., Babin, B.J., \& Anderson,R.E. (2010). Multivariate Data Analysis Seventh Edition. New Jersey (US): Pearson.

Han J, Kamber M. (2006). Data Mining: Concept and Techniques second editions. Elsevier: Morgan Kaufman Publisher.

Han, J., \& Kamber, M. (2001). Data Mining: Concepts and Techniques. USA: Academic Press.

Halkidi M, Yannis B, Michalis V. 2001. On Clustering Validation Techniques. Journal of Intelligent Information System 17(2/3):107-145. Netherlands.

Johnson, R.A. \& Whinchern, D.W. (2007). Applied multivariate statistical analysis sixth edition. Prentice Hall: New Jersey.

Kaufman, Lonard, \& Rousseeuw, Peter J. (1990). Finding Group in Data. John Willey \& Sons, Inc. Kanada.

Karti, H.S, Irhamah. (2013). Pengelompokan Kabupaten/Kota di Provinsi Jawa Timur Berdasarkan Indikator Pendidikan SMA/SMK/MA dengan Metode C-Means dan Fuzzy C-Means. Jurnal Sains dan Seni Pomits 2(2): 288-293.

Kantardzic, M.(2011). Data Mining: Concepts, Models, Methods, and Algorithms. USA : John Wiley \& Son, Inc.

Lewis,Paul D. (2010).R For Madicine and Biology.Jones and Bartlett Publisher

Mattjik, A.A., \& Made Sumertajaya. (2002). Perancangan Percobaan dengan Aplikasi SAS Dan Minitab. Jilid I. Edisi kedua. Bogor: IPB Press.

Prayudho, BJ. (2009). Analisis Cluster. [terhubung berkala]. http://prayudha. wordpress.com /2008/12/30 /analisiscluster/.[29 November 2015].

Pusat Bahasa Departemen Pendidikan Nasional. (2013). Pendidikan. Diakses dari http://www. sarjanaku .com /2012/12/pengertian-pendidikan-menurut-para-ahli.html Kamis, 28 Februari 2013. 
Rizqia, Hamzulida R. (2016). Faktor-Faktor Yang Mempengaruhi Angka Partisipasi Kasar (Apk) Jenjang Pendidikan Sekolah Menengah Pertama Pada Masyarakat Pesisir Di Kecamatan Sarang Kabupaten Rembang Tahun 2015. Semarang: UNNES.

Ridwan, Mujib, Hadi Suyono, M. Sarosa. (2013). Penerapan Data Mining Untuk Evaluasi Kinerja Akademik Mahasiswa Menggunakan Algoritme Naive Bayes Classifier. Jurnal EECCIS Vol.7, No. 1, Juni 2013.

Rizal, Annas, S. \& Hakim, R.B.F. (2015). Metode K-Means Cluster dan Fuzzy C-Means Cluster (Studi Kasus : Indeks Pembangunan Manusia di Kawasan Indonesia Timur Tahun 2012). Yogyakarta : Universitas Islam Indonesia.

Syafrina M. (2015). Penggerombolan daerah Indonesia berdasarkan peubah IPM dengan Fuzzy-rataan dan K-medoid. Bogor (ID): Institut Pertanian Bogor.

Satato, B.D., Khotimah, B. K., \& Muhammad, A. (2015). PengelompokanTingkat Kesehatan Masyarakat menggunakan Shelf Organizing Maps Dengan Cluster Validation Idb dan I-Dunn. Seminar Nasional Aplikasi Teknologi Informasi.

Sartono, B., Farid M. Affendi, Utami Dyah Syafitri, I. Made Sumertajaya. dan Yenni Angraeni. (2003). Analisis Peubah Ganda. Bogor: IPB.

Tan, P., Steinbach, M., \& Kumar, V. (2006). Introduction to Data Mining. USA: Pearson Education,Inc.

Tiro, M.A., Sukarna., \& Aswi. (2010). Statistika Deskriptif Peubah Banyak. Edisi pertama. Makassar Andira Publisher.

Widiastuti, Astri. 2017. Implementasi algoritma Partitioning Around Medoids (PAM) Untuk Pengelompokan Skolah Menengah tas di DIYBerdasarkan Nilai Daya Serap Ujian Nasional. Yogyakarta: Universitas Sanata Dharma Yogyakarta. 